\title{
Insulin-like growth factor-1 content and pattern of expression correlates with histopathologic grade in diffusely infiltrating astrocytomas
}

\author{
Hirofumi Hirano, M. Beatriz S. Lopes, Edward R. Laws, Jr., Tetsuhiko Asakura, \\ Masamichi Goto, Joan E. Carpenter, Larry R. Karns, and Scott R. VandenBerg ${ }^{1}$ \\ Departments of Neurosurgery [H.H., T.A.] and Pathology [M.G.], Kagoshima University, Kagoshima, Japan \\ 890-8520; and Department of Pathology, Division of Neuropathology [M.B.S.L., J.E.C., L.R.K., S.R.V.], and \\ Department of Neurological Surgery [E.R.L., Jr.], University of Virginia Health Sciences Center, \\ Charlottesville, VA 22908
}

Studies of experimental tumorigenesis have strongly implicated signaling of the insulin-like growth factor 1 (IGF-1) as a key component in astrocytic neoplasia; however, its role in the growth of low-grade and malignant human tumors is not well understood. Correlative analyses of IGF-1, p53, and Ki-67 (MIB-1) immunohistochemistry and IGF-1 receptor (IGF-1R) mRNA expression were performed to examine the cellular pattern of IGF-1 signaling in 39 cases of astrocytoma (World Health Organization grades II-IV). Tumor cells expressing IGF-1 and IGF-1R were present in all tumor grades. The proportion of tumor cells that expressed IGF-1 correlated with both histopathologic grade and Ki-67 labeling indices, while expression of IGF-1R mRNA correlated with Ki-67 indices. In cases where stereotactic tissue sampling could be identified with a specific tumor area by neuroimaging features, the numbers of IGF-1 immunoreactive cells correlated with the tumor zones of highest cellularity and Ki-67 labeling. In glioblastomas, the localization of IGF-1 immunoreactivity was notable for several

Received 24 August 1998, accepted 6 January 1999.

${ }^{1}$ Address correspondence and reprint requests to Scott R. VandenBerg, M.D., Ph.D., Department of Pathology, Neuropathology, University of Virginia Health Science Center, Box 214, Charlottesville, VA 22908.

${ }^{2}$ Abbreviations used are as follows: EGFR, epidermal growth factor receptor; FF, form factor; IGF-1, insulin-like growth factor-1; IGF-1R, insulin-like growth factor-1 receptor; LI, labeling indices; SSC, standard sodium citrate (buffer); WHO, World Health Organization. features: frequent accentuation in the perivascular tumor cells surrounding microvascular hyperplasia; increased levels in reactive astrocytes at the margins of tumor infiltration; and selective expression in microvascular cells exhibiting endothelial/pericytic hyperplasia. IGF-1R expression was particularly prominent in tumor cells adjacent to both microvascular hyperplasia and palisading necrosis. These data suggest that IGF-1 signaling occurs early in astroglial tumorigenesis in the setting of cell proliferation. The distinctive correlative patterns of IGF-1 and IGF-1R expression in glioblastomas also suggest that IGF-1 signaling has an association with the development of malignant phenotypes related to aberrant angiogenesis and invasive tumor interactions with reactive brain. Neuro-Oncology 1, 109-119, 1999 (Posted to Neuro-Oncology [serial online], Doc. 98-16, April 30, 1999. URL <neuro-oncology.mc.duke.edu>)

$\longrightarrow$ rowth factors have been implicated at multiple stages of astroglial tumorigenesis (Louis, 1997). In the development of low-grade astrocytomas, these factors may play a role in stimulating cellular proliferation in the absence of aberrant cell cycle regulation (Cavenee et al., 1997). The possibility of aberrant autocrine loops has been proposed for a number of growth factor/receptor systems, and a causative role for platelet-derived growth factor or its receptor as stimulating proliferation has been the most strongly implicated (Westermark et al., 1995). Previous studies of astrocytic tumors have demonstrated altered growth factor activity- 
in addition to platelet-derived growth factor-associated with either changes in ligand or receptor expression in basic fibroblast growth factor, transforming growth factor-alpha or -beta, and IGF-12 (Ekstrand et al., 1991; Hussaini et al., 1996; Jennings et al., 1991, Takahashi et al., 1990; Van Meir, 1995; Zumkeller et al., 1993).

During anaplastic progression of astrocytomas or the formation of de novo glioblastomas, aberrant up regulation of EGF signaling pathway(s) via EGFR activation (EGFR gene amplification) or via converging downstream signals (via PLC $\gamma$, mitogen-activated protein kinase, and phosphatidylinositol-3 kinase pathways) (Yamada et al., 1997) from other growth factor receptors may govern a variety of malignant phenotypic properties, including invasiveness and angiogenesis. IGF-1 is one such growth factor with partial convergent downstream signaling that may have biologic effects both during early astrocytic tumorigenesis and in malignant progression. Although IGF-1 ligands and IGF-1Rs have been previously detected in human astrocytomas, the present studies address the previously uncharacterized spatial expression of IGF-1 and IGF-1R in both low-grade and malignant astrocytomas in relation to the proliferative indices, WHO grade, and p53 immunoreactivity of the tumors. Alterations in p53 immunoreactive expression were examined, since functional p53 may regulate IGF-1 signaling by affecting either receptor or binding protein expression (Buckbinder et al., 1995; Werner et al., 1996). IGF-1 and IGF-1R are expressed in all tumor grades with an increased percentage of IGF-1 immunoreactive cells in tumors with higher proliferative indices and higher histopathologic grades. Within glioblastomas, there appears to be a more complex spatial expression of IGF1 and IGF-1R within distinct tumor zones as well as within specific cell cycle subpopulations. This study suggests that astroglial tumorigenesis may involve IGF-1 signaling associated with cell proliferation in both low- and high-grade tumors and that the distinctive patterns of IGF-1 and IGF-1R expression in glioblastomas suggest that IGF-1 signaling may have an additional role(s) in malignant tumor progression and synergistic interactions with adjacent, reactive brain.

\section{Materials and Methods}

\section{Tumors}

A total of 39 cases of primary astrocytic tumors were analyzed for these studies. Five cases were sampled separately by both stereotactic biopsy and open resection (2 WHO grade II, 2 WHO grade III, and 1 WHO grade IV), 23 cases by open resection only (4 WHO grade II, 3 WHO grade III, and 16 WHO grade IV), 11 cases by stereotactic biopsy alone (7 WHO grade II, 4 WHO III). Tissue samples from all cases were analyzed by $\mathrm{ABC}$ immunohistochemistry for Ki-67 (MIB-1 epitope), p53 (mutant and wild-type epitopes), and IGF-1 peptide. Thirty-four of the 39 cases were also analyzed for the IGF-1R mRNA by in situ hybridization. When multiple sections were available for study, only those sections that demonstrated the diagnostic histopathologic features for a given WHO grade were analyzed.
Seventy-four tissue specimens from the 16 stereotactically operated cases were classified according to the neuroimaging location: Area 1, peripheral to the tumor margin; Area 2, low density by CT and high intensity by T2weighted MRI; Area 3, interface zone between the contrast-enhanced area and the nonenhanced area (zone of high intensity on T2-weighted MRIs; zone of slightly higher density by CT); Area 4, contrast-enhanced area; Area 5, nonenhanced center of tumor.

\section{Immunohistochemistry}

Four-micron paraffin sections of formalin-fixed tissues were mounted on poly-L-lysine-coated glass slides. Tissues were deparaffinized, fully hydrated through graded ethanols, and incubated in methanol with $0.5 \% \mathrm{H}_{2} \mathrm{O}_{2}$ for $30 \mathrm{~min}$ at $22^{\circ} \mathrm{C}$ to block endogenous peroxidase activity. Specimens for Ki-67 and p53 were additionally processed by heating with a 750 -watt microwave 2 times at $5 \mathrm{~min}$ each in $10 \mathrm{mM}$ citrate buffer ( $\mathrm{pH} \mathrm{6)}$. Primary mouse monoclonal antibodies (Ki-67, MIB-1, Immunotech, Westbrook, ME; p53, DO-1, Immunotech; IGF-1, antihuman IGF-1, Upstate Biochemical, Lake Placid, NY) were applied and allowed to react for $2 \mathrm{~h}$ at $22^{\circ} \mathrm{C}(\mathrm{Ki}-67$ and $\mathrm{p} 53)$ or $18 \mathrm{~h}$ at $4^{\circ} \mathrm{C}$ (IGF-1). Secondary biotinylated antisera were followed by the avidin-biotincomplex (Vectastain, Vector Laboratories, Burlingame, CA); the reaction was developed with 3-39-diaminobenzine-tetrahydrochloride and counterstained with Mayer's hematoxylin.

To calculate the nuclear LI for Ki-67 and p53, 200 nuclei for each stereotactic tissue section and 400-2000 nuclei for each tissue section from the open resection specimens were analyzed. IGF-1 immunoreactivity was graded according to either the relative percentage of immunoreactive cells (IGF-1 stain ratio) or the relative immunostaining intensity (IGF-1 stain intensity). For IGF-1sr, the following indices were used: 0, for the absence of any IGF-1 immunoreactivity; $1+$, for $<10 \%$ labeled cells; $2+$, for $10-50 \%$ labeled cells; or $3+$, for $>50 \%$ labeled cells. For grading IGF-1 immunoreactive intensity, relative levels of IGF-1si were graded from 0 , $1+, 2+$, or $3+$.

\section{In Situ Hybridization}

A cDNA containing $291 \mathrm{bp}$ of the 59 untranslated region and $283 \mathrm{bp}$ of the amino terminal coding region of the $\alpha$-peptide of the IGF-1R was excised from $4.4 \mathrm{~kb}$ cDNA of the human IGF-1R (Kaleko et al., 1990). The antisense and sense probe $\left({ }^{35} \mathrm{~S}\right.$ labeled) were prepared by in vitro transcription with RNA polymerase T7 and polymerase T3, respectively. An antisense probe for $\alpha$-actin was prepared from clone EST00003 (Genbank M61955, Bethesda, MD) identified by TIGR (The Institute for Genomic Research, Gaithersburg, MD) (Adams et al., 1991) and purchased from the American Type Culture Collection (Manassas, VA). A fragment of approximately $500 \mathrm{bp}$ (bases 125-653) representing the 59 end was subcloned into the EcoR1 and Eagl sites of pBluescript-SK. For in situ hybridization, the plasmid was linearized with EcoR1, and the ${ }^{35}$ S-labeled 
probe was prepared by in vitro transcription with RNA polymerase T3.

Deparaffinized, formalin-fixed tissue sections were prepared as described for immunohistochemistry. Sections were then immersed in $4 \%$ paraformaldehyde for $10 \mathrm{~min}$, washed in $0.5 \mathrm{SSC}$ buffer for $5 \mathrm{~min}$, treated with $3 \mu \mathrm{g} / \mathrm{ml}$ proteinase $\mathrm{K}$ (Boehringer Mannheim, Indianapolis, IN) in buffer $(500 \mathrm{mM} \mathrm{NaCl}, 10 \mathrm{M}$ Tris-HCl, $\mathrm{pH}$ 8.0 ) for $30 \mathrm{~min}$, and washed in $0.5 \mathrm{SSC}$ for $10 \mathrm{~min}$. The slides were then incubated for $1 \mathrm{~h}$ with $150 \mu \mathrm{l}$ of prehybridization buffer $(50 \%$ formamide, $0.3 \mathrm{M} \mathrm{NaCl}, 20$ $\mathrm{mM}$ Tris-HCl, $5 \mathrm{mM}$ EDTA, 1 [Denhardt's solution, $10 \%$ dextran sulfate, $10 \mathrm{mM}$ dithiothreitol]). The hybridization mixture $(50 \mu \mathrm{l}$ per slide) consisted of the prehybridization buffer with the addition of $1\left(10^{6} \mathrm{cpm}\right.$ of ${ }^{35}$ S-labeled probe and $20 \mu \mathrm{g}$ of yeast tRNA per slide). Each slide was hybridized with $50 \mu$ of hybridization mixture and incubated overnight at $55^{\circ} \mathrm{C}$ in a humidified chamber. After twice washing (10 min each with 2 SSC with $10 \mathrm{mM} \beta$-mercaptoethanol and $1 \mathrm{mM}$ EDTA), slides were washed with $20 \mu \mathrm{g} / \mathrm{ml}$ of RNase A in the buffer (500 mM NaCl, $10 \mathrm{M}$ Tris- $\mathrm{HCl}, \mathrm{pH}$ 8.0) for 30 $\min$ at $22^{\circ} \mathrm{C}$. Continuous washing was performed under the following conditions: 2 changes of 2 SSC with 10 $\mathrm{mM} \beta$-mercaptoethanol and $1 \mathrm{mM}$ EDTA at $22^{\circ} \mathrm{C}$ for 10 min, 2 changes of 0.1 SSC with $10 \mathrm{mM} \beta$-mercaptoethanol and $1 \mathrm{mM}$ EDTA at $55^{\circ} \mathrm{C}$ for $2 \mathrm{~h}, 2$ changes of $0.5 \mathrm{SSC}$ at room temperature for $10 \mathrm{~min}$.

Following dehydration through graded ethanols with $0.3 \mathrm{M}$ ammonium acetate, the slides were dried and dipped in Kodak NTB2 Nuclear Emulsion diluted 1:1 with $0.6 \mathrm{M}$ ammonium acetate. The slides were allowed to dry at room temperature and transferred to a lightproof, desiccation box at $4^{\circ} \mathrm{C}$. After 3 weeks of exposure, the slides were developed for $2 \mathrm{~min}$ in Kodak D-19, washed in water, and fixed for $2 \mathrm{~min}$ in Kodak Rapid Fixer. The slides were washed and stained with hematoxylin and eosin. The expression of IGF-1R mRNA was evaluated by the intensity of grain signal: $0,1+, 2+$, or $3+$.

\section{Statistical Analysis}

The Kruskal-Wallis analysis was used as a nonparametric method, and Dunn's method (Hollander and Wolfe, 1973) was used for multiple comparisons. For populations whose normal distribution and equality of variance were confirmed, one-way analysis of variance (ANOVA) was used and Fisher's least significant difference procedure was used for multiple comparisons. Additionally, Spearman's rank correlation coefficient was used to estimate the strength of correlations.

To further address the influence of IGF-1 immunoreactivity, IGF-1R mRNA expression, or p53 LI on Ki-67 LI, we performed a multiple regression analysis. The analysis with a stepwise method was performed using $\mathrm{Ki}$ 67 LI as a dependent variable and p53 LI, IGF-1 immunoreactivity, and IGF-1R mRNA expression as independent variables. Before the analysis, qualitative scoring data were converted to a quantitative scale. For example, IGF-1R expression $(0,1+, 2+, 3+)$ was coded into 3 variables: IGF-1R $1+(0$ or 1$)$; IGF-1R $2+(0$ or 1$)$; IGF-1R3+ (0 or 1$)$. Other independent variables we used were IGF-1sr1+, IGF-1sr2+, IGF-1sr3+, IGF-1si1+, IGF1si2+, IGF-1si3+, dark p53 LI, and light p53 LI.

\section{Cell Counts and Morphometry in Stereotactic Specimens}

Four different areas per hematoxylin and eosin-stained section were digitized as $200 \mu \mathrm{m} \times 200 \mu \mathrm{m}$ fields $(1000$ $\times 1000$ pixels). The images were analyzed on a Macintosh computer using "Image" software (National Institutes of Health, http://rsb.info.nih.gov/nih-image/). An FF (form factor), as an index of nuclear pleomorphism, was calculated by the formula $\mathrm{FF}=4 \times \pi \times \mathrm{A} / \mathrm{L}^{2}$, where $\mathrm{A}$ is the nuclear area and $L$ is the nuclear circumference for each nucleus. Mean values for each section were calculated, based on nuclear counts. Low FF values corresponded to increased nuclear pleomorphism. Although the ratio of the longest and shortest nuclear diameter of each digitized nucleus also correlated with the degree of nuclear pleomorphism, only the FF was used for statistical analysis.

\section{Results}

\section{Expression of IGF-1}

IGF-1 immunoreactivity was detected in the cytoplasm and cellular processes of a fraction of tumor cells in all specimens. Gemistocytic cells were well stained in the cytosol, whereas the smallest, more anaplastic cells showed the lowest levels of IGF-1. Immunoreactive cells were relatively scattered in a diffuse pattern in the lowgrade tumors (Fig. 1A). In contrast, the immunoreactivity was quite heterogeneous within the high-grade astrocytomas (Fig. 1B). In glioblastomas, both the number and staining intensity of tumor cell processes were typically highest in perivascular areas (Fig. 1E). In addition, the tumor microvessels exhibiting endothelial/pericytic proliferation were intensely immunoreactive for IGF-1 (Fig. 2A), compared with nonproliferative vessels in glioblastomas and lower-grade astrocytomas. IGF-1 was also present in reactive astrocytosis at the brain-tumor interface. The intensity of IGF-1 reaction was particularly strong at the edge of glioblastomas (Fig. 2C). By contrast, astrocytes in infiltrating zones of low-grade astrocytomas were weakly positive.

The highest levels of IGF-1 immunoreactivity, as measured by both the percentage of immunoreactive cells and relative staining intensity, were found in glioblastomas. The relative percentage of IGF-1 immunoreactive cells strongly correlated with the WHO grade of the tumor (II-IV; $r_{s}=0.489, P<0.0001$ ), but the trend for increased staining intensity did not show a similar correlation (Table 1).

\section{IGF-1R mRNA Expression}

IGF-1R mRNA was expressed in all grades of astrocytomas as determined by in situ hybridization (Figs. 1C and 1D). Although IGF-1R expression tended to be greatest in the higher-grade astrocytomas (Fig. 1D), expression was also present in low-grade tumors (Fig. 1C) 

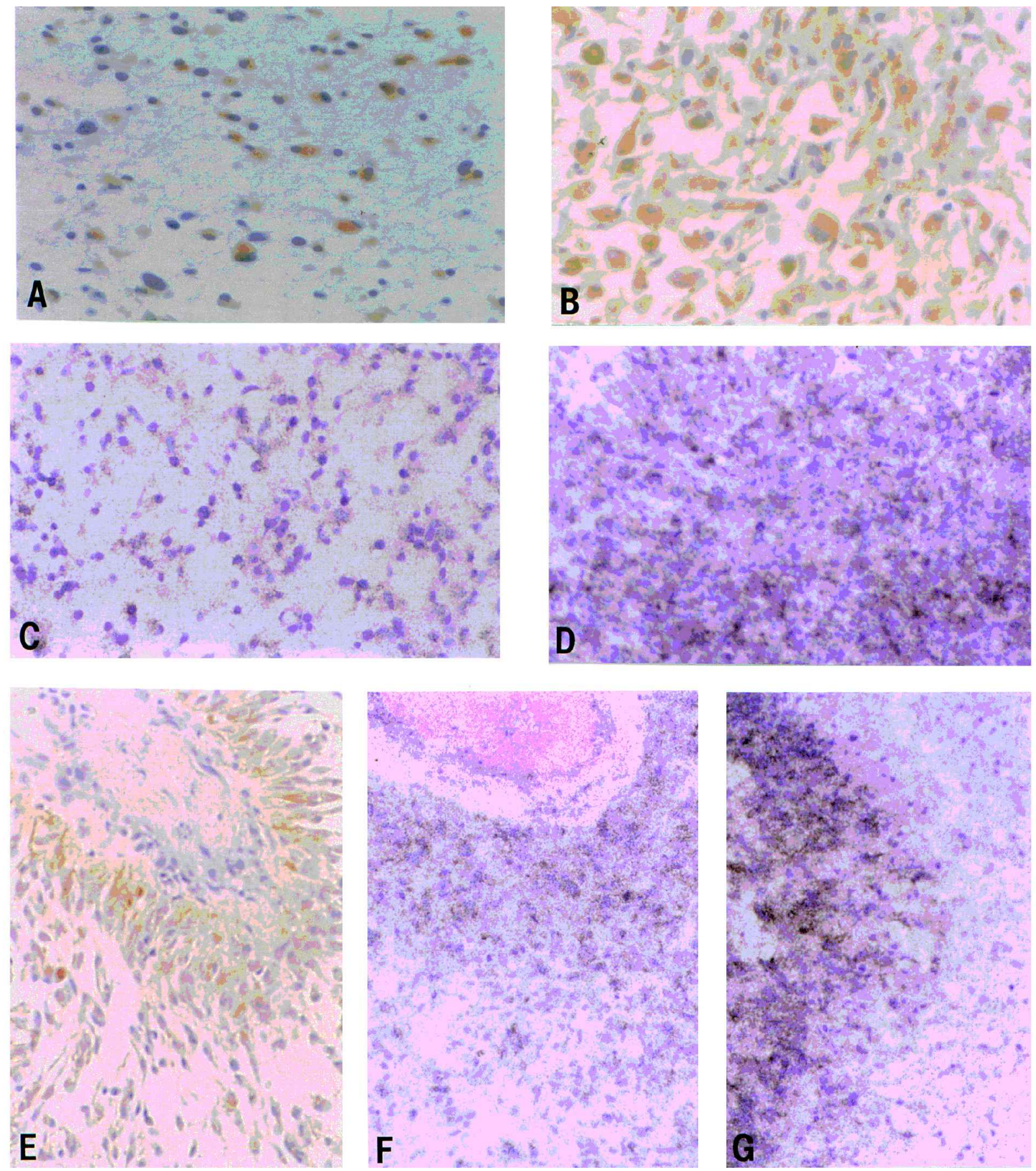

Fig. 1. Insulin-like growth factor 1 (IGF-1) and IGF-1 receptor (IGF-1R) expression in astrocytic tumors. A. IGF-1 immunoreactivity in astrocytoma WHO grade II. B. IGF-1 immunoreactivity in a glioblastoma. C. IGF-1R mRNA expression in an astrocytoma WHO grade II. D. IGF-1R mRNA expression in a glioblastoma. E. Strong IGF-1 immunoreactivity in perivascular tumor cells in a glioblastoma. F. IGF-1R mRNA expression, which is strongest in perivascular tumor cells in a glioblastoma. G. Overexpression of IGF-1R mRNA in tumor cells surrounding palisading necrosis in a glioblastoma.

such that there was sufficient signal to distinguish them from adjacent brain. Within glioblastomas, similar to IGF-1 expression, the highest level of IGF-1R mRNA was present in perivascular tumor cells (Fig. 1F). Distinct from the pattern of IGF-1 expression, the tumor cells surrounding areas of necrosis, especially palisading necrosis (Fig. 1G), showed marked expression of IGF-
1R without a similar difference in IGF-1 expression. In addition, microvessels exhibiting endothelial/pericytic proliferation had elevated IGF-1R mRNA similar to IGF-1 expression (Fig. 2B). Statistical analysis demonstrated that IGF-1R mRNA expression in tumor cells had a slight correlation with WHO tumor grade $\left(r_{s}=0.292, P=0.0216\right.$; Table 1$)$. 

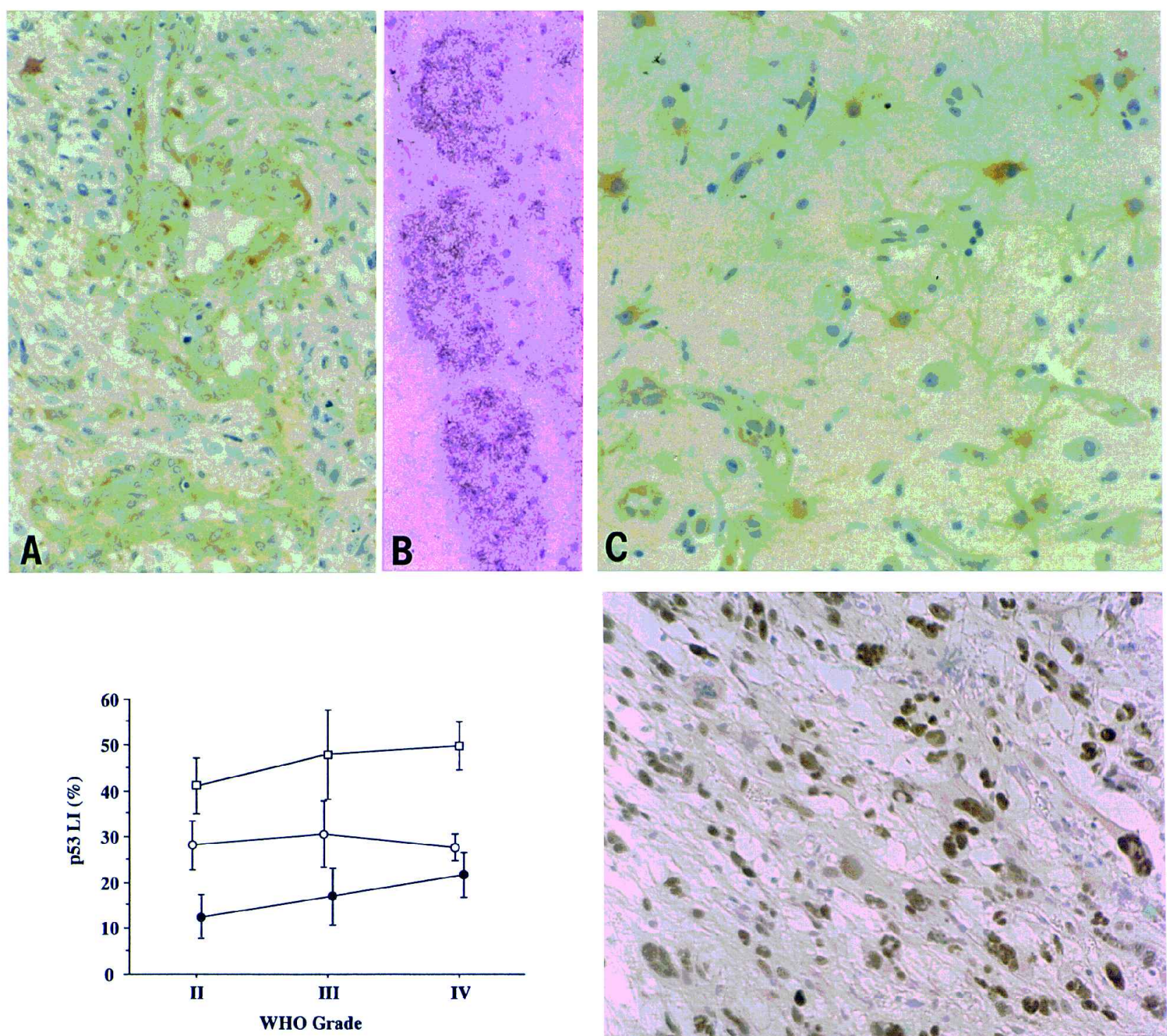

口 Total p53 LI ○ Light p53 LI $\bullet$ Dark p53 LI

D

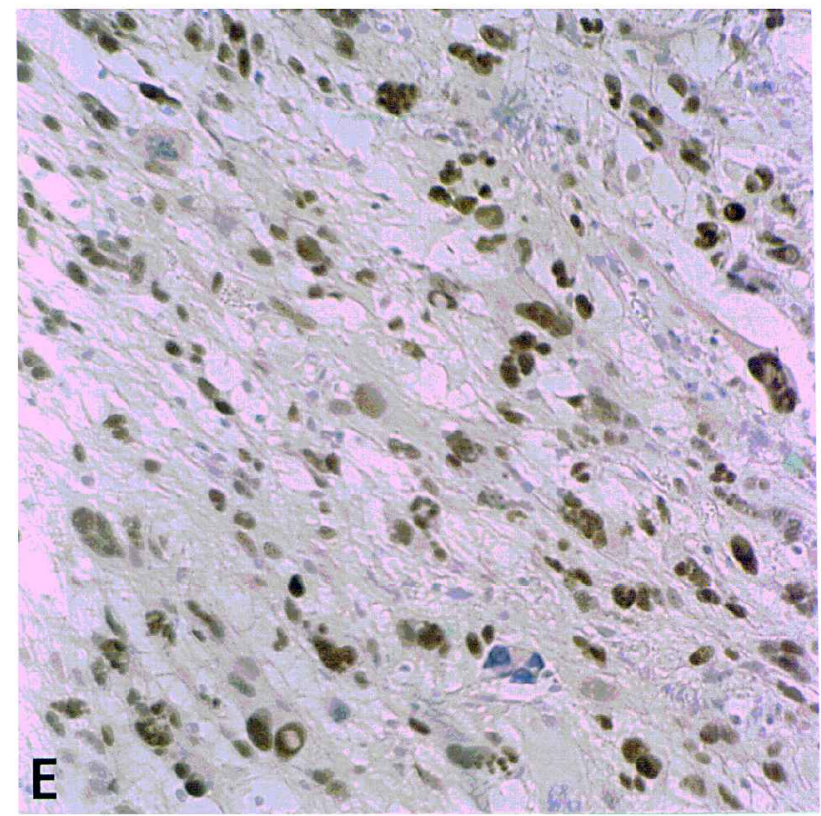

Fig. 2. Insulin-like growth factor 1 (IGF-1) and IGF-1 receptor (IGF-1R expression and p53 protein reactivity in astrocytic tumors. A. IGF-1 immunoreactivity in microvessels exhibiting endothelial/pericytic proliferation in a glioblastoma. B. Similarly, high IGF-1R mRNA expression in microvessels exhibiting endothelial/pericytic proliferation. C. IGF-1 immunoreactivity in reactive astrocytes at the periphery of a glioblastoma. D. Dark p53 LI, which has a slight correlation with WHO grade $\left(r_{s}=0.268, P=0.0364\right)$. The $r_{s}$ of total p53 LI and light p53 LI with WHO grade was $0.414(P=0.2721)$ and $0.035(P=0.7873)$, respectively. E. p53 immunohistochemistry in a glioblastoma exhibiting darkly and lightly stained nuclei.

\section{Ki-67 and p53 Immunohistochemistry}

Staining intensity of nuclear immunoreactivity for Ki-67 was relatively homogeneous among the positive cells. Generally, the higher the grade, the higher the LI. The Ki-67 LI correlated well with the WHO tumor grade (Table 2).

Nuclear immunoreactivity for $\mathrm{p} 53$ had two relative levels of intensity, representing conspicuously dark and light staining. Distinctly dark and light immunoreactive nuclei were usually randomly mixed in any given area (Fig. 2E). The differentiation between dark- and light-stained nuclei was comparatively analyzed using a case of glioblastoma with documented p53 gene mutation as the dark standard. The percentage of darkly stained p53 nuclei increased slightly with higher WHO tumor grades $\left(r_{s}=0.268, P=0.0364\right.$; Fig. 2D). The light-stained p53 LI was relatively unchanged in all WHO grades.

\section{Correlation of IGF-1, IGF-1R, Ki-67, and p53 Data}

The IGF-1 staining ratio had a correlation $\left(r_{s}=0.504\right.$, $P<0.0001$; Fig. 3A left) with Ki-67 LI in the same sam- 
Table 1. IGF-1 immunoreactivity and IGF-1R expression according to tumor grade by World Health Organization classification

\begin{tabular}{lcccc} 
& & \multicolumn{3}{c}{ Mean rank values } \\
\cline { 3 - 5 } Grade & Tissue section $^{\mathrm{a}}$ & IGF-1 staining ratio & IGF-1 staining intensity $^{\mathrm{b}}$ & IGF-1R expression $^{\mathrm{d}}$ \\
\hline II & 19 & $22.4^{\mathrm{e}}$ & 29.9 & 22.6 \\
III & 15 & 26.6 & 28.9 & 28.8 \\
IV & 29 & $41.1^{\mathrm{f}}$ & 35.1 & 37.2 \\
\hline
\end{tabular}

IGF-1, insulin-like growth factor 1; IGF-1R, insulin-like growth factor-1 receptor.

${ }^{a}$ The number of tissue sections examined.

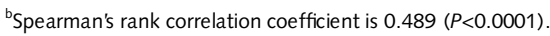

'Spearman's rank correlation coefficient is $0.143(P=0.2586)$.

${ }^{\mathrm{d} S}$ Spearman's rank correlation coefficient is $0.292(P=0.0216)$.

${ }^{\mathrm{e}}$ versus ${ }^{\mathrm{f}}: P<0.005$.

ples that were used for analysis of IGF-1R mRNA. This correlation was also present in both the total specimen group (153) from the 39 cases $\left(r_{s}=0.592, P<0.0001\right)$ as well the tissue limited to stereotactic biopsy (Table 4). This result was independent of the selection of subgroup. The Ki-67 LI and IGF-1R expression were correlated (Fig. 3A right) and the Spearman's rank correlation coefficient was $0.517 \quad(P<0.0001)$. With respect to p53 immunohistochemistry, a slight correlation between dark p53 LI and IGF-1R expression was present $\left(r_{s}=0.299\right.$, $P=0.0197$; Fig. 3B right); however, there was no significant correlation between total p53 LI and IGF-1R expression.

Stepwise multiple regression analysis identified three effective independent variables: the highest percentage of IGF-1 immunoreactive cells (IGF-1sr3+), the greatest levels of IGF-1R expression (IGF-1R3+), and dark p53 LI. Other variables were eliminated because their influences on the Ki-67 LI were not statistically significant. The equation finally obtained was as follows: fitted $\mathrm{Ki}-67 \mathrm{LI}$ $=0.234($ dark p53 LI $)+0.138($ IGF-1R3 $)+0.103($ IGF$1 \mathrm{sr} 3+)$, and the multiple correlation coefficient $(r)$ was 0.828 . Each $P$ value for the regression coefficient was as follows: $P<0.0001$ (dark p53 LI); $P=0.0004$ (IGF-1R3+); $P=0.0002$ (IGF-1sr3+). The distribution of real Ki-67 LI and calculated values as fitted Ki-67 LI obtained by the multiple regression equation is shown in Fig. 4. This analysis suggests that $\mathrm{Ki}-67 \mathrm{LI}$ is strongly affected by dark p53 LI (Fig. 3B left), a high expression of IGF-1R, and high values for the percentage of IGF-1 immunoreactive cells. However, these data cannot exclude the converse possibility that a highly proliferative state drives the expression of IGF-1 and IGF-1R.

Table 2. Relationship between $\mathrm{Ki}-67$ labeling indices (MIB-1) and tumor grade by World Health Organization classification

\begin{tabular}{lcc} 
Tumor grade & Ki-67 LI\% (mean) & \pm SEM \\
\hline II & 3.8 & 1.1 \\
III & 10.2 & 2.4 \\
IV & 19.0 & 3.0 \\
\hline
\end{tabular}

LI, Labeling indices; SEM, standard error of the mean.

$\mathrm{Ki}-67 \mathrm{LI}$ correlated with $\mathrm{WHO}$ grade $\left(r_{s}=0.517, P<0.0001\right)$. There was a difference among three grades by Kruskal-Wallis $(P=0.0002)$, and Dunn's method was used for multiple comparisons. Mean ranks of Ki- $67 \mathrm{LI}$ in each grade were II, 18.5; III, 32.0; IV, 40.8.

\section{Stereotactic Biopsy Correlations}

For the stereotactic cases, the mean cellularity, morphometric nuclear FF, Ki-67 LI, and IGF-1 immunohistochemistry were analyzed according to the neuroimaging localization (areas 1-5) as previously described. There was a significant correlation between $\mathrm{Ki}-67 \mathrm{LI}$ and the centripetal location in tumors (Table 3) with $P=0.0004$ and $r_{s}=0.419$. The mean cellularity also significantly correlated with the zonal location (Table 3). The degree of nuclear pleomorphism, as quantified by the mean FF, increased toward the centers of tumors (Table 3). Both the percentage of IGF-1 immunoreactive cells and the staining intensity correlated with the zonal localization of the tumor cells (Table 3 ). The percentage of IGF-1 immunoreactive tumor cells also correlated with cellularity and the Ki-67 LI (Table 4), but the IGF-1 staining intensity did not. Nuclear pleomorphism (FF) also correlated with levels of IGF-1 immunoreactivity (Table 4).

\section{Discussion}

Astrocytic tumorigenesis and anaplastic progression is a complex multistep process that results in a sustained, heterogeneous cell proliferation; alterations in cell cycle regulation; increased brain invasiveness; and aberrant angiogenesis. Although an increase in proliferative activity is currently postulated to underlie the initial development of both low- and high-grade tumors, the roles of specific growth factors for regulating this response in the various tumor grades are not well understood. Functional IGF-1R signaling appears to be essential for neoplastic transformation in multiple cell lineages, including embryonal fibroblasts using SV40 large T-antigen transfection (Sell et al., 1993). In the brain, IGF-1 functions as a glial growth factor during development and in reactive astrocytosis (Coppola et al., 1994; Gammeltoft et al., 1988a; Sandberg et al., 1988). Experimental studies have strongly suggested a key role for IGF-1 signaling in astrocytic tumorigenesis (Rubin and Baserga, 1995).

In cultured glioma cells, IGF-1 stimulates proliferation (Merrill and Edwards, 1990; Rubin and Baserga, 1995; Wang et al., 1997) and blocks apoptosis (Resnicoff et al., 1995; Yang et al., 1996). Other glial mitogens (Van 

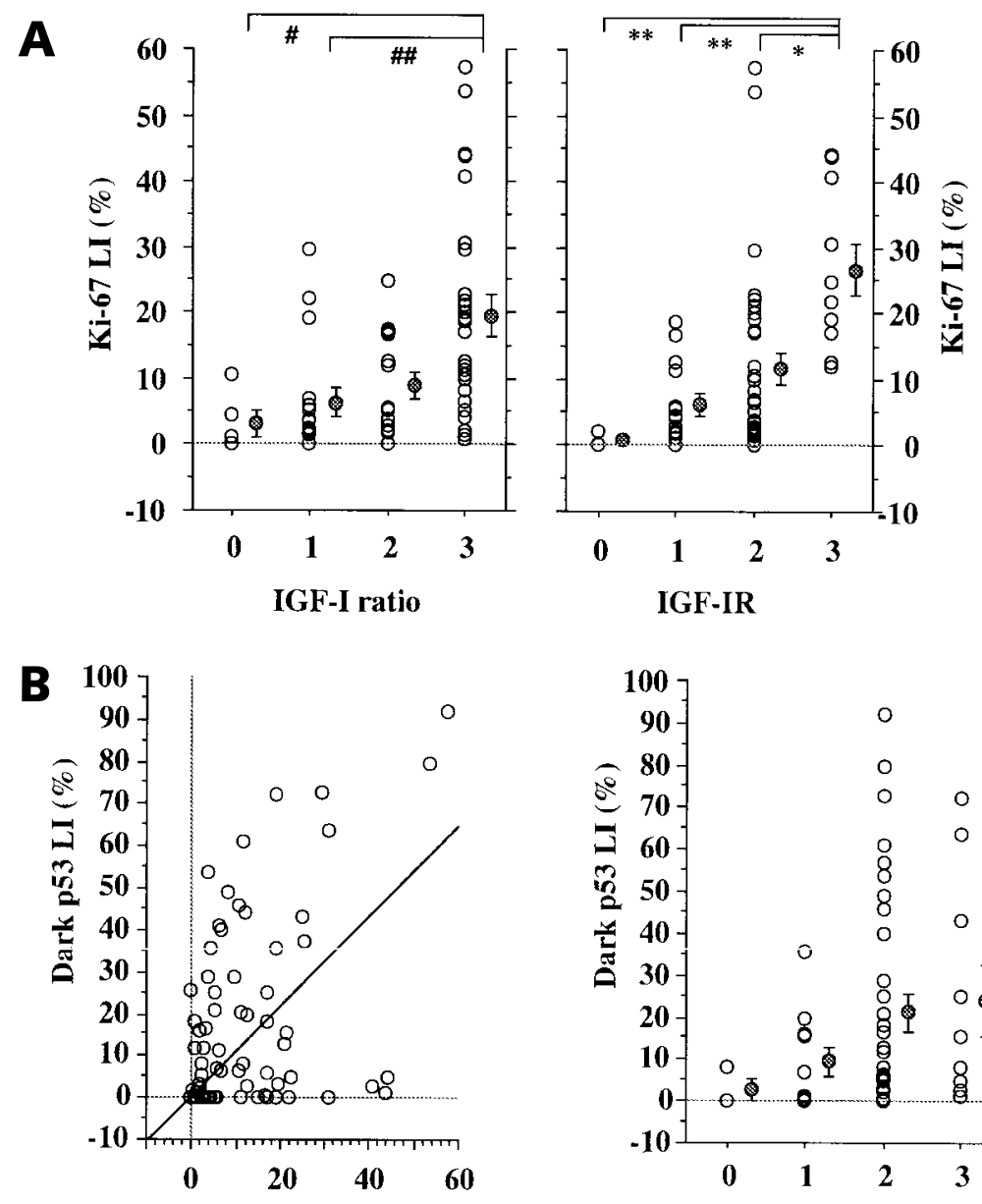

Ki-67 LI (\%)

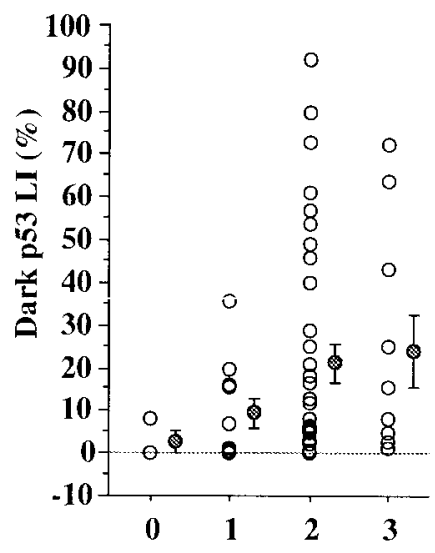

IGF-IR Expression

Fig. 3. Relationship between insulin-like growth factor 1 (IGF-1), IGF-1 receptor (IGF-1R), Ki-67, and p53 in astrocytic tumors. A. Relationship between Ki-67 LI and IGF-1 staining ratio and IGF-1R expression. There were differences among the mean ranks of Ki-67 LI by IGF-1 ratio ( $P=0.0013$ by Kruskal-Wallis) and among those by IGF-1R expression ( $P=0.0002$ by Kruskal-Wallis). The differences between two groups are based on Dunn's method of multiple comparison (\#, $P<0.05$; \#\#, $P<0.005 ;{ }^{*}, P<0.01 ;{ }^{*}, P<0.001$ ). Spearman's rank correlation coefficient $\left(r_{s}=0.504, P<0.0001\right)$ indicated a correlation between IGF-1 staining ratio and Ki-67 LI. IGF-1R expression and Ki-67 LI also correlated well and the $r_{s}$ was $0.517(P<0.0001)$. However, no differences were seen among the mean ranks of Ki- 67 by IGF- 1 intensity $(P=0.5237$ by KruskalWallis ) and the grade of IGF-1 staining intensity $\left(r_{s}=0.079, P<0.533\right)$ (not shown). B. Relationship between dark p53 LI and Ki- $67 \mathrm{LI}$ and IGF$1 \mathrm{R}$ expression. Ki-67 LI was affected by dark p53 LI $\left(r_{s}=0.669, P<0.0001\right)$. Although the statistical differences were not detected by KruskalWallis, Spearman's rank correlation indicated a correlation between dark p53 LI and IGF-1R expression $\left(r_{s}=0.299, P=0.0197\right)$.

der Ven et al., 1997), including EGF (Chernausek, 1993) and raised levels of lactate, can increase IGF-1 secretion by cultured glioma cells (Straus and Burke, 1995). Reduced IGF-1 levels also accompany decreased cellular proliferation after up regulation of gap junction formation (Bradshaw et al., 1993) or following treatment with prostaglandin- $\mathrm{A}_{2}$ (Bui et al., 1997) in cultured glioma cells. Antisense knockout and mutant transfection studies with IGF-1R demonstrate that these tumorigenic properties of IGF-1 are mediated via IGF-1R (Burgaud et al., 1995; Resnicoff et al., 1995, 1996) and that constitutive IGF-1R signaling is sufficient for autonomous growth of glioma cells in serum-free cell culture (Ambrose et al., 1994).

Previous studies have demonstrated that IGF-1 peptide, IGF binding proteins, and IGF-1R are expressed in human astrocytic tumors (Gammeltoft et al., 1988b; Glick et al., 1989; McCusker et al., 1990; Merril and Edwards, 1990; Sandberg et al., 1988; Zumkeller et al., 1993) at levels higher than in fetal brain (Sandberg et al., 1988). The present study is the first to systematically examine the cellular pattern of IGF-1 and IGF-1R expression in a large series of diffuse-type astrocytomas (WHO grades II-IV) with correlations to MIB-1 proliferative indices, p53 immunohistochemistry, and the previously well-characterized heterogeneous tumor zones defined by neuroimaging. The localization of the peptide and receptor are consistent with the putative neoplastic paracrine/autocrine nature of IGF-1 signaling in diffuse-type astrocytomas. The increased expression of IGF-1 in reactive astrocytes, especially at the margin of glioblastomas, also raises the possibility that IGF-1 may be a paracrine growth factor at the 
Table 3. Stereotatic biopsy correlations

\begin{tabular}{|c|c|c|c|c|c|c|}
\hline \multirow[b]{2}{*}{ Location } & \multirow[b]{2}{*}{$\begin{array}{l}\text { Tissue } \\
\text { section }^{\mathrm{a}}\end{array}$} & \multirow[b]{2}{*}{$\begin{array}{c}\text { Cell } \\
\text { number }^{\mathrm{b}}\end{array}$} & \multirow[b]{2}{*}{$\begin{array}{l}\text { Form } \\
\text { factor }^{c}\end{array}$} & \multirow[b]{2}{*}{$\begin{array}{c}\mathrm{Ki}-67 \mathrm{LI}^{\mathrm{d}} \\
\%\end{array}$} & \multicolumn{2}{|c|}{ Mean rank values } \\
\hline & & & & & $\begin{array}{c}\text { IGF-1 } \\
\text { staining ratio }\end{array}$ & $\begin{array}{c}\text { IGF-1 } \\
\text { staining intensity }\end{array}$ \\
\hline 1 & 9 & $39.6^{g}$ & $0.722^{g}$ & $0.8^{g}$ & $15.0^{g}$ & $14.5^{g}$ \\
\hline 2 & 34 & 62.9 & $0.706^{g}$ & 2.2 & $36.5^{\mathrm{h}}$ & $37.7^{\mathrm{h}}$ \\
\hline 3 & 13 & $131.4^{i}$ & 0.693 & $5.6^{\mathrm{h}}$ & $38.7^{\mathrm{h}}$ & $34.4^{h}$ \\
\hline 4 & 16 & $129.0^{j}$ & $0.629^{h}$ & $4.6^{\mathrm{h}}$ & $47.8^{k}$ & $50.3^{k}$ \\
\hline 5 & 2 & 111.0 & $0.537^{h}$ & $6.5^{\mathrm{h}}$ & $66.5^{i}$ & $55.3^{h}$ \\
\hline
\end{tabular}

IGF-1, insulin-like growth factor 1; IGF-1R, insulin-like growth factor 1 receptor; LI, labeling indices.

${ }^{2}$ The number of tissue sections examined.

${ }^{\text {b}}$ Spearman's rank correlation coefficient is $0.433(P<0.0001)$.

'Spearman's rank correlation coefficient is $-0.304(P=0.0094)$.

${ }^{\mathrm{d}}$ Spearman's rank correlation coefficient is $0.419(P=0.0004)$.

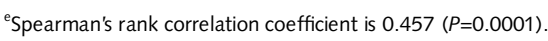

fSpearman's rank correlation coefficient is $0.429(P=0.0002)$.

${ }^{g}$ versus $^{h}, P<0.05$; versus ${ }^{~}, P<0.01$; versus ${ }^{j}, P<0.005$; versus ${ }^{k}, P<0.001$.

infiltrating tumor edge. The direct relationships between IGF-1 content to the MIB-1 proliferative indices and WHO grade in all tumor samples (open resection and stereotactic biopsies) implicate IGF-1 as a mitogenic factor in human astrocytomas. Within specific neuroimaging zones in the stereotactic biopsies (WHO grades II-IV), the strong association of IGF-1 expression with MIB-1 proliferative indices, cellularity, and nuclear pleomorphism also suggests that IGF-1 has a role in cellular proliferation in both low- and high-grade astrocytic tumors. The more robust correlation between the percentage of IGF-1 immunoreactive cells and proliferative indices or WHO grade, compared with that for IGF-1 staining intensity, suggests that these biologic and histopathologic parameters are sensitive to threshold levels without additional detectable effects at higher focal concentrations. Alternatively, estimation of immunohistochemical staining inten-

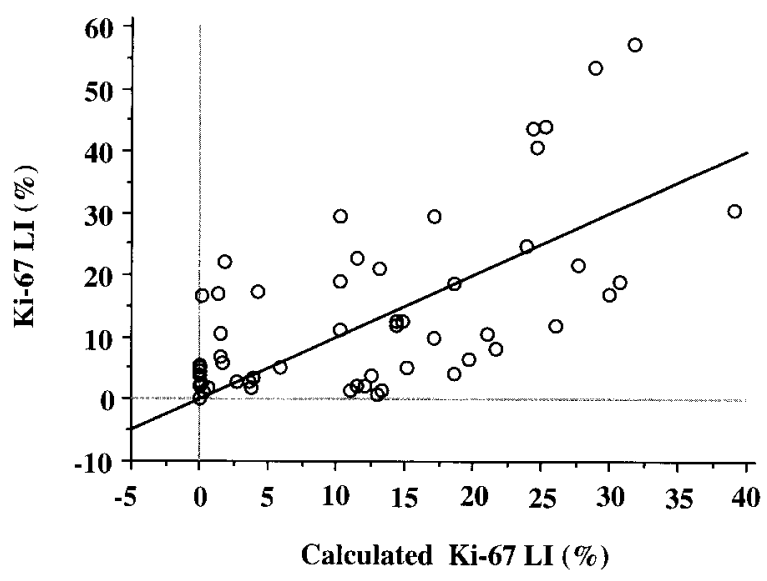

Fig. 4. Distribution of real Ki-67 LI and calculated Ki-67 LI. The distribution of real $\mathrm{Ki}-67 \mathrm{LI}$ is shown on the $\mathrm{y}$-axis and calculated $\mathrm{Ki}-67$ $\mathrm{LI}$ on the $\mathrm{x}$-axis. The equation was as follows: fitted Ki-67 $\mathrm{LI}=0.234$ (dark p53)+0.138(IGF-1R3+)+0.103(IGF-1sr3+). Multiple correlation coefficient $(r)$ of the regression model was 0.828 . sity is likely to have more technical limitations than simple determination of immunoreactive cells.

The geographic patterns of IGF-1 expression in glioblastomas, as distinct from the random expression pattern in low-grade tumors, suggest that IGF-1 signaling may also have biologic activities related to the attenuation of apoptosis and to aberrant microvascular hyperplasia. The up regulation of IGF-1R expression in malignant astrocytes surrounding palisading necrosis without an increase in IGF-1 expression would suggest that this up regulation may be related to anti-apoptotic signaling mediated by IGF-1 (Kulik et al., 1997). Recently, it was reported that cells expressing the mutant receptor (12801283 ) are fully responsive to IGF-1-mediated mitogenesis, but are not transformed (Li et al., 1996); whereas the transforming domain of the IGF-1R appears to be localized between residues 1245 and 1310 (Hongo et al., 1996). Accordingly, there is a possibility that the downstream signaling via IGF-1R for proliferation and transformation may be distinct. The abundant IGF-1R mRNA expression that did not directly coincide with proliferative activity may be related to the role of IGF-1 signaling in blocking apoptosis. This activity may be especially relevant to necrotizing micro-environments, such as in those cells palisading around geographic necrosis.

The tumor cells in areas immediately adjacent to the aberrant hyperplastic microvasculature demonstrated high levels of both IGF-1 and IGF-1R expression. Likewise, the microvascular cells associated with endothelial/pericytic hyperplasia had notable up regulation of both IGF-1 and IGF-1R expression. Such an up regulation of IGF-1R expression may be, in part, stimulated by increased IGF-1 levels (Roberts, 1996). Such a conspicuous pattern suggests the possibility of both paracrine and autocrine IGF-1 signaling in association with this microvascular response. This may be related to the direct role of IGF-1 signaling in angiogenesis (Bar et al., 1988; Kluge et al., 1997; Nakao-Hayashi et al., 1992) or the increased expression of vascular endothelial growth factor in response to IGF-1 signaling (Goad et al., 1996; 
Table 4. Relationship between IGF-1, Ki-67 labeling indices, form factor, and number of cells in stereotatic biopsy

\begin{tabular}{lccr} 
Classification & Number of cells & Form factor & Ki-67 LI (\%) \\
\hline IGF-1 ratio & $P=0.0314(\mathrm{~K}-\mathrm{W})$ & $P=0.0361$ (ANOVA) & $P=0.0008(\mathrm{~K}-\mathrm{W})$ \\
$(0,1+, 2+, 3+)$ & $r_{s}=0.296, P=0.0114(\mathrm{~S})$ & $r_{s}=-0.313, P=0.0075(\mathrm{~S})$ & $r_{s}=0.413, P=0.0004(\mathrm{~S})$ \\
IGF-1 intensity & $P=0.4621(\mathrm{~K}-\mathrm{W})$ & $P=0.0071$ (ANOVA) & $P=0.1575(\mathrm{~K}-\mathrm{W})$ \\
$(0,1+, 2+, 3+)$ & $r_{s}=0.215, P=0.1304(\mathrm{~S})$ & $r_{s}=-0.366, P=0.0018(\mathrm{~S})$ & $r_{s}=0.208, P=0.075(\mathrm{~S})$ \\
\hline
\end{tabular}

ANOVA, one-way ANOVA; IGF-1, insulin-like growth factor 1; IGF-1R, insulin-like growth factor 1 receptor; K-W, Kruskal-Wallis analysis; S, Spearman's rank correlation $\left(r_{s}\right.$ : Spearman's rank correlation coefficient).

Kim et al., 1998; Punglia et al., 1997). The secretion of plasminogen-activating proteinases by the malignant perivascular astrocytes (Landau et al., 1994; Yamamoto et al., 1994) may also promote this IGF-1-induced microangiogenesis (Sato et al., 1993). Despite these suggestive data, the biologic mechanisms for the endothelial/pericytic proliferation in glioblastomas, as an example of a complex aberrant microvascular hyperplasia, await further elucidation.

The increased numbers of reactive astrocytes expressing increased IGF-1 at the infiltrating margin of glioblastomas in comparison to low-grade astrocytomas and normal brain raises the possibility of IGF-1 acting as a paracrine growth factor at the infiltrating tumor edge. Nonneoplastic astrocytes up regulate IGF-1 expression in response to injury (Garcia-Estrada et al., 1992), especially in subacute gemistocytic astrocytosis (Hussaini et al., 1996). Although the receptor signaling pathways mediating this response are not defined, EGFR activation would be a putative mechanism (Ekstrand et al., 1995), since increased EGF expression is a heterogeneous feature within a number of malignant astrocytic tumors (Bello, 1996; Sanfilippo et al., 1993). Focally increased levels of IGF-1 and EGF would also produce a synergistic effect in the invasive phenotype by increasing cellular motility (Faber-Elman et al., 1996) via common downstream signaling pathways (Sasaoka et al., 1994; Tournier et al., 1994). IGF-1 signaling, with respect to specific biologic effects, may be more heterogeneous and complex than what IGF-1/IGF-1R expression would suggest. Activation of synergistic downstream pathways with other growth factors and the variable tumoral expression of a number of IGF binding proteins that also modulate IGF-1 activity at the cell surface (Blum et al., 1989; Busby et al., 1988; De Mellow and Baxter, 1988; Ekstrand et al., 1995; Elgin et al., 1987; Jones and Clemmons, 1995; Mohan et al., 1989; Rao et al., 1995; Ross et al., 1989; Shimasaki et al., 1990; Zheng et al., 1998) would most likely confer additional levels of complexity. Characterization of the specific mechanisms underlying this putative complexity in situ are beyond the scope of the present study, but clearly merit future work.

Wild p53 may down regulate IGF-1 signaling via suppressing the IGF-1R promoter (Werner et al., 1996) or decreasing the bioavailability of IGF-1 by inducing IGF binding protein-3 expression (Buckbinder et al., 1995). In this context, the distinction between dark and light nuclear p53 immunoreactivity, as defined by a case of glioblastoma with documented p53 gene mutation as the dark standard, suggests an interesting possibility with respect to IGF-1R expression. Variation in p53 immunohistochemical staining intensity has been previously described (Jaros et al., 1992; Rubio et al., 1993), and it may be partly due to wild-type p53 protein accumulation without mouse double-minute-2 (MDM2) gene amplification (Fritsche et al., 1993; Rubio et al., 1993). While not definitive, the population of lightstained p53 cells may thus include those cells with high levels of wild-type p53, but with no gene mutation, while the dark p53 nuclear immunoreactivity may indicate cells with aberrant p53 function. Dark p53 immunoreactivity correlated with increased IGF-1R expression in this study, suggesting another putative pathway affecting IGF-1 signaling in astrocytomas. The multiple regression model in our study in which $\mathrm{Ki}-67 \mathrm{LI}$ has strong correlation with IGF-1, IGF-1R mRNA expression and dark-stained p53 LI suggests the possibility that IGF-1 signaling is up regulated in a complex constellation of growth factors affecting astrocytic proliferation in tumor development and growth. The characteristic patterns of IGF-1 and IGF-1R expression in glioblastomas also emphasize that multiple factors affecting IGF-1 signaling may be a determinant of the biological behavior in malignant astrocytomas.

\section{Acknowledgments}

We are grateful to Dr. Gerald R. Hankins for advice regarding statistical analyses.

\section{References}

Adams, M.D., Kelley, J.M., Gocayne, J.D., Dubnick, M., Polymeropoulos, M.H., Xiao, H., Merril, C.R., Wu, A., Olde, B., Moreno, R.F., Kerlavage, A.R., McCombie, W.R., and Venter, J.C. (1991) Complementary DNA sequencing: Expressed sequence tags and human genome project. Science 252, 1651-1666.
Ambrose, D., Resnicoff, M., Coppola, D., Sell, C., Miura, M., Jameson, S., Baserga, R., and Rubin, R. (1994) Growth regulation of human glioblastoma T98G cells by insulin-like growth factor-1 and its receptor. J. Cell. Physiol. 159, 92-100.

Bar, R.S., Boes, M., Dake, B.L., Booth. B.A., Henley, S.A., and Sandra, A. 
(1988) Insulin, insulin-like growth factors, and vascular endothelium. Am. J. Med. 85, 59-70.

Bello, L. (1996) Urinary epidermal growth factor (EGF) levels and epidermal growth factor receptor (EGF-R) expression in human cerebral tumors. Clinical considerations. J. Neurosurg. Sci. 40, 167-182.

Blum, W.F., Jenne, E.W., Reppin, F., Kietzmann, K., Ranke, M.B., and Bierich, J.R. (1989) Insulin-like growth factor I (IGF-I)-binding protein complex is a better mitogen than free IGF-I. Endocrinology 125, 766-772.

Bradshaw, S.L., Naus, C.C., Zhu, D., Kidder, G.M., D'Ercole, A.J., and Han, V.K. (1993) Alterations in the synthesis of insulin-like growth factor binding proteins and insulin-like growth factors in rat $\mathrm{C} 6$ glioma cells transfected with a gap junction connexin43 cDNA. Regul. Pept. 48, 99-112.

Buckbinder, L., Talbott, R., Velasco-Miguel, S., Takenaka, I., Faha, B., Seizinger, B.R., and Kley, N. (1995) Induction of the growth inhibitor IGFbinding protein 3 by p53. Nature 377, 646-649.

Bui, T., Kuo, C., Rotwein, P., and Straus, D.S. (1997) Prostaglandin A2 specifically represses insulin-like growth factor-I gene expression in C6 rat glioma cells. Endocrinology 138, 985-993.

Burgaud, J.L., Resnicoff, M., and Baserga, R. (1995) Mutant IGF-I receptors as dominant negatives for growth and transformation. Biochem. Biophys. Res. Commun. 214, 475-481.

Busby, W.H., Jr., Klapper, D.G., and Clemmons, D.R. (1988) Purification of a 31,000-dalton insulin-like growth factor binding protein from human amniotic fluid. J. Biol. Chem. 263, 14203-14210.

Cavenee, W.K., Bigner, D.D., Newcomb, E.W., Paulus, W., and Kleihues, P. (1997) Diffuse astrocytomas. In: Kleihues, P., and Cavenee, W.K. (Eds.), Pathology and Genetics of Tumours of the Nervous System. Lyon: International Agency for Research on Cancer. pp. 2-9.

Chernausek, S.D. (1993) Insulin-like growth factor-1 (IGF-I) production by astroglial cells regulation and importance for epidermal growth factorinduced cell replication. J. Neurosci. Res. 34, 189-197.

Coppola, D., Ferber, A., Miura, M., Sell, C., D'Ambrosio, C., Rubin, R., and Baserga, R. (1994) A functional insulin-like growth factor I receptor is required for the mitogenic and transforming activities of the epidermal growth factor receptor. Mol. Cell. Biol. 14, 4588-4595.

De Mellow, J.S.M., and Baxter, R.C. (1988) Growth hormone-dependent insulin-like growth factor (IGF) binding protein both inhibits and potentiates IGF-I stimulated DNA synthesis in human skin fibroblasts. Biochem. Biophys. Res. Commun. 156, 199-204.

Ekstrand, A.J., James, C.D., Cavenee, W.K., Seliger, B., Pettersson, R.F., and Collins, V.P. (1991) Genes for epidermal growth factor receptor, transforming growth factor alpha, and epidermal growth factor and their expression in human gliomas in vivo. Cancer Res. 51, 2164-2172.

Ekstrand, A.J., Liu, L., He, J., Hamid, M.L., Longo, N., Collins, V.P., and James, C.D. (1995) Altered subcellular location of an activated and tumour-associated epidermal growth factor receptor. Oncogene 10, 1455-1460.

Elgin, R.G., Busby, W.H., Jr., and Clemmons, D.R. (1987) An insulin-like growth factor (IGF) binding protein enhances the biologic response to IGF-I. Proc. Natl. Acad. Sci. USA 84, 3254-3258.

Faber-Elman, A., Solomon, A., Abraham, J.A., Marikovsky, M., and Schwartz, M. (1996) Involvement of wound-associated factors in rat brain astrocyte migratory response to axonal injury: In vitro simulation. J. Clin. Invest. 97, 162-171.

Fritsche, M., Haessler, C., and Brandner, G. (1993) Induction of nuclear accumulation of the tumor-suppressor protein p53 by DNA-damaging agents. Oncogene 8, 307-318.

Gammeltoft, S., Ballotti, R., Nielsen, F.C., Kowalski, A., and Van Obberghen, E. (1988a) Receptors for insulin-like growth factors in the central nervous system: sStructure and function. Horm. Metab. Res. 20, 436-442.

Gammeltoft, S., Ballotti, R., Kowalski, A., Westermark, B., and Van Obberghen, E. (1988b) Expression of two types of receptor for insulin-like growth factors in human malignant glioma. Cancer Res. 48, 1233-1237.
Garcia-Estrada, J., Garcia-Segura, L.M., and Torres-Aleman, I. (1992) Expression of insulin-like growth factor I by astrocytes in response to injury. Brain Res. 592, 343-347.

Glick, R.P., Gettleman, R., Patel, K., Lakshman, R., and Tsibris, J.C. (1989) Insulin and insulin-like growth factor I in brain tumors: Binding and in vitro effects. Neurosurgery 24, 791-797.

Goad, D.L., Rubin, J., Wang, H., Tashjian, A.H., Jr., and Patterson, C. (1996) Enhanced expression of vascular endothelial growth factor in human SaOS-2 osteoblast-like cells and murine osteoblasts induced by insulin-like growth factor I. Endocrinology 137, 2262-2268.

Hollander, M., and Wolfe, D.A. (1973) Nonparametric Statistical Methods. New York: John Wiley \& Sons.

Hongo, A., D'Ambrosio, C., Miura, M., Morrione, A., and Baserga, R. (1996) Mutational analysis of the mitogenic and transforming activities of the insulin-like growth factor I receptor. Oncogene 12, 1231-1238.

Hussaini, I.M., Lopes, M.B.S., Musante, D.B., Karns, L.R., and VandenBerg, S.R. (1996) Expression of IGF-1 and IGF-1R in reactive astrocytes and astrocytic tumors. J. Neuropathol. Exp. Neurol. 55, 606. (Abstract)

Jaros, E., Perry, R.H., Adam, L., Kelly, P.J., Crawford, P.J., Kalbag, R.M. Mendelow, A.D., Sengupta, R.P., and Pearson, A.D. (1992) Prognostic implications of p53 protein, epidermal growth factor receptor, and Ki-67 labelling in brain tumours. Br. J. Cancer 66, 373-385.

Jennings, M.T., Maciunas, R.J., Carver, R., Bascom, C.C., Juneau, P., Misulis, K., and Moses, H.L. (1991) TGF beta 1 and TGF beta 2 are potential growth regulators for low-grade and malignant gliomas in vitro: Evidence in support of an autocrine hypothesis. Int. J. Cancer 49, 129-139.

Jones, J.I., and Clemmons, D.R. (1995) Insulin-like growth factors and their binding proteins: Biological actions. Endocr. Rev. 16, 3-34.

Kaleko, M., Rutter, W.J., and Miller, A.D. (1990) Overexpression of the human insulinlike growth factor I receptor promotes ligand-dependent neoplastic transformation. Mol. Cell. Biol. 10, 464-473.

Kim, K.W., Bae, S.K., Lee, O.H., Bac, M.H., Lee, M.J., and Park, B.C. (1998) Insulin-like growth factor II induced by hypoxia may contribute to angiogenesis of human hepatocellular carcinoma. Cancer Res. 58, 348-351.

Kluge, A., Zimmermann, R., Weihrauch, D., Mohri, M., Sack, S., Schaper, J., and Schaper, W. (1997) Coordinate expression of the insulin-like growth factor system after microembolisation in porcine heart. Cardiovasc. Res. 33, 324-331.

Kulik, G., Klippel, A., and Weber, M.J. (1997) Antiapoptotic signalling by the insulin-like growth factor I receptor, phosphatidylinositol 3-kinase, and Akt. Mol. Cell. Biol. 17, 1595-1606.

Landau, B.K., Kwaan, H.C., Verrusio, E.N., and Brem, S.S. (1994) Elevated levels of urokinase-type plasminogen activator and plasminogen activator inhibitor type-1 in malignant human brain tumors. Cancer Res. 54, 1105-1108.

Li, S., Resnicoff M., and Baserga, R. (1996) Effect of mutations at serines 1280-1283 on the mitogenic and transforming activities of the insulin-like growth factor I receptor. J. Biol. Chem. 271, 12254-12260.

Louis, D.N. (1997) A molecular genetic model of astrocytoma histopathology. Brain Pathol. 7, 755-764.

McCusker, R.H., Camacho-Hubner, C., Bayne, M.L., Cascieri, M.A., and Clemmons, D.R. (1990) Insulin-like growth factor (IGF) binding to human fibroblast and glioblastoma cells: The modulating effect of cell released IGF binding proteins (IGFBPs). J. Cell. Physiol. 144, 244-253.

Merrill, M.J., and Edwards, N.A. (1990) Insulin-like growth factor-I receptors in human glial tumors. J. Clin. Endocrinol. Metab. 71, 199-209.

Mohan, S., Bautista, C.M., Wergedal, J., and Baylink, D.J. (1989) Isolation of an inhibitory insulin-like growth factor (IGF) binding protein from bone cell-conditioned medium a potential local regulator of IGF action. Proc. Natl. Acad. Sci. USA 86, 8338-8342.

Nakao-Hayashi, J., Ito, H., Kanayasu, T., Morita, I., and Murota, S. (1992) Stimulatory effects of insulin and insulin-like growth factor I on migration 
and tube formation by vascular endothelial cells. Atherosclerosis $\mathbf{9 2}$, 141-149.

Punglia, R.S., Lu, M., Hsu, J., Kuroki, M., Tolentino, M.J., Leough, K., Levy, A.P., Levy, N.S., Goldberg, M.A., D'Amato, R.J., and Adamis, A.P. (1997) Regulation of vascular endothelial growth factor expression by insulin-like growth factor I. Diabetes 46, 1619-1626.

Rao, G.N., Delafontaine, P., and Runge, M.S. (1995) Thrombin stimulates phosphorylation of insulin-like growth factor-1 receptor, insulin receptor substrate-1, and phospholipase C-gamma 1 in rat aortic smooth muscle cells. J. Biol. Chem. 270, 27871-27875.

Resnicoff, M., Burgaud, J.L., Rotman, H.L., Abraham, D., and Baserga, R. (1995) Correlation between apoptosis, tumorigenesis, and levels of insulin-like growth factor I receptors. Cancer Res. 55, 3739-3741.

Resnicoff, M., Li, W., Basak, S., Herlyn, D., Baserga, R., and Rubin, R. (1996) Inhibition of rat $\mathrm{C} 6$ glioblastoma tumor growth by expression of insulinlike growth factor I receptor antisense mRNA. Cancer Immunol. Immunother. 42, 64-68.

Roberts, C.T., Jr. (1996) Control of insulin-like growth factor (IGF) action by regulation of IGF-I receptor expression. Endocrine J. 43 (Suppl.), S49-55.

Ross, M., Francis, G.L., Szabo, L., Wallace, J.C., and Ballard, F.J. (1989) Insulinlike growth factor (IGF)-binding proteins inhibit the biological activities of IGF-I and IGF-2 but not des-(1-3)-IGF-1. Biochem. J. 258, 267-272.

Rubin, R., and Baserga, R. (1995) Insulin-like growth factor-I receptor. Its role in cell proliferation, apoptosis, and tumorigenicity. Lab. Invest. 73, 311-331.

Rubio, M.P., von Deimling, A., Yandell, D.W., Wiestler, O.D., Gusella, J.F., and Louis, D.N. (1993) Accumulation of wild-type p53 protein in human astrocytomas. Cancer Res. 53, 3465-3467.

Sandberg, A.C., Engberg, C., Lake, M., von Holst, H., and Sara, V.R. (1988) The expression of insulin-like growth factor I and insulin-like growth factor II genes in the human fetal and adult brain and in glioma. Neurosci. Lett. 93, 114-119.

Sanfilippo, J.S., Rao, C.V., Guarnaschelli, J.J., Woost, P.G., Byrd, V.M., Jones, E., and Schultz, G.S. (1993) Detection of epidermal growth factor and transforming growth factor alpha protein in meningiomas and other tumors of the central nervous system in human beings. Surg. Gynecol. Obstet. 177, 488-496.

Sasaoka, T., Rose, D.W., Jhun, B.H., Saltiel, A.R., Draznin, B., and Olefsky, J.M. (1994) Evidence for a functional role of Shc proteins in mitogenic signaling induced by insulin, insulin-like growth factor- 1 and epidermal growth factor. J. Biol. Chem. 269, 13689-13694.

Sato, Y., Okamura, K., Morimoto, A., Hamanaka, R., Hamaguchi, K., Shimada, T., Ono, M., Kohno, K., Sakata, T., and Kuwano, M. (1993) Indispensable role of tissue-type plasminogen activator in growth factor-dependent tube formation of human microvascular endothelial cells in vitro. Exp. Cell Res. 204, 223-229.
Sell, C., Rubini, M., Rubin, R., Liu, J.P., Efstratiadis, A., and Baserga, R. (1993) Simian virus 40 large tumor antigen is unable to transform mouse embryonic fibroblasts lacking type 1 insulin-like growth factor receptor. Proc. Natl. Acad. Sci. USA 90, 11217-11221.

Shimasaki, S., Uchiyama, F., Shimonaka, M., and Ling, N. (1990) Molecular cloning of the cDNAs encoding a novel insulin-like growth factor-binding protein from rat and human. Mol. Endocrinol. 4, 1451-1458.

Straus, D.S., and Burke, E.J. (1995) Glucose stimulates IGF-I gene expression in C6 glioma cells. Endocrinology 136, 365-368.

Takahashi, J.A., Mori, H., Fukumoto, M., Igarashi, K., Jaye, M., Oda, Y., Kikuchi, H., and Hatanaka, M. (1990) Gene expression of fibroblast growth factors in human gliomas and meningiomas: Demonstration of cellular source of basic fibroblastic growth factor mRNA and peptide in tumor tissues. Proc. Natl. Acad. Sci. USA 87, 5710-5714.

Tournier, C., Pomerance, M., Gavaret, J.M., and Pierre, M. (1994) MAP kinase cascade in astrocytes. Glia 10, 81-88.

Van der Ven, L.T., Van Buul-Offers, S.C., Gloudemans, T., Roholl, P.J., Sussenbach, J.S., and Den Otter, W. (1997) Histamine-stimulated expression of insulin-like growth factors in human glioma cells. Br. J. Cancer 75 , 1091-1097.

Van Meir, E.G. (1995) Cytokines and tumors of the central nervous system. Glia 15, 264-288.

Wang, Z.H., Ma, J., Zeng, B.J., Catanese, V.M., Samuels, S., Gama Sosa, M.A., and Kolodny, E.H. (1997) Correlation of glioma cell regression with inhibition of insulin-like growth factor 1 and insulin-like growth factor-binding protein-2 expression. Neuroendocrinology 66, 203-211.

Werner, H., Karnieli, E., Rauscher, F.J., and LeRoith, D. (1996) Wild-type and mutant p53 differentially regulate transcription of the insulin-like growth factor I receptor gene. Proc. Natl. Acad. Sci. USA 93, 8318-8323.

Westermark, B., Heldin, C.H., and Nister, M. (1995) Platelet-derived growth factor in human glioma. Glia 15, 257-263.

Yamada, M., Ikeuchi, T., and Hatanaka, H. (1997) The neurotrophic action and signalling of epidermal growth factor. Prog. Neurobiol. 51, 19-37.

Yamamoto, M., Sawaya, R., Mohanam, S., Rao, V.H., Bruner, J.M., Nicolson, G.L., Ohshima, K., and Rao, J.S. (1994) Activities, localizations, and roles of serine proteases and their inhibitors in human brain tumor progression. J. Neurooncol. 22, 139-151.

Yang, B.C., Chang, H.M., Wang, Y.S., Chen, R.F., and Lin, S.J. (1996) Transient induction of apoptosis in serum-starved glioma cells by insulin and IGF-1. Biochim. Biophys. Acta 1314, 83-92.

Zheng, B., Clarke, J.B., Busby, W.H., Duan, C., and Clemmons, D.R. (1998) Insulin-like growth factor-binding protein- 5 is cleaved by physiological concentrations of thrombin. Endocrinology 139, 1708-1714.

Zumkeller, W., Saaf, M., and Rahn, T. (1993) Insulin-like growth factor (IGF)I, -II and IGF-binding proteins in the cyst fluid of a patient with astrocytoma. Childs Nerv. Sys. 9, 100-103. 